\title{
Relationships between blood lead, blood pressure, serum cholesterol and body mass index of non-occupationally exposed males, residents of Abeokuta, Nigeria
}

\author{
Iheoma Mary ADEKUNLE ${ }^{1 *}$, John Ndudi OSUAGWU ${ }^{1}$, Olusegun Olubunmi \\ BABALOLA $^{2}$, Toyin Ayodele AROWOLO ${ }^{1}$ and Olusegun Olukayode ODUKOYA ${ }^{3}$ \\ ${ }^{I}$ Department of Environmental Management and Toxicology, University of Agriculture, Abeokuta, Nigeria. \\ ${ }^{3}$ Department of Biochemistry, Obafemi Awolowo University, Ile-Ife, Nigeria. \\ ${ }^{3}$ Department of Chemistry, University of Agriculture, Abeokuta, Nigeria. \\ * Corresponding author, E-mail: imkunle@yahoo.com
}

\begin{abstract}
Study examined the associations between blood $-\mathrm{Pb}$, serum cholesterol, diastolic and, systolic blood pressures, hematocrit, body weight, age and body mass index in 528 study subjects comprising $50 \%$ cigarette smoking and 50\% non-smoking male residents of Abeokuta, Nigeria, aged from 15 to 80 years. Blood Pb was measured using atomic absorption spectrophotometer and the other variables were determined using standard procedures. Generally, interwoven relationships between all the parameters were established. Cigarette smoking appeared to be an additional source of $\mathrm{Pb}$ intake as the mean value for smokers $(42 \pm 12 \mu \mathrm{g} / \mathrm{dl})$ exceeded that for non-smokers $(34 \pm 11 \mu \mathrm{g} / \mathrm{dl})$ by approximately $24 \%$. Blood $\mathrm{Pb}$ related positively to systolic blood pressure of non-smokers $(r=+0.138)$ and diastolic blood pressure for smokers $(r=+0.129)$ at $p<0.05$. It also associated significantly with serum cholesterol for non-smokers $(r=+0.114)$ and body mass index for non-smoker $(\mathrm{r}=+0.110)$ at $\mathrm{p} \leq 0.10$. Systolic blood pressure related to age for both smokers $(\mathrm{r}=+0.272)$ and non-smokers $(\mathrm{r}=+0.182)$ at $\mathrm{p} \leq 0.05$. Results suggest that non-occupational exposure to $\mathrm{Pb}$ in Nigeria is related to plasma lipid profiles and blood pressure, which are risk factors to hypertension.

(C) 2009 International Formulae Group. All rights reserved.
\end{abstract}

Keywords: Serum metal, lipid, systolic pressure, diastolic pressure, anthropometric factors, correlations

\section{INTRODUCTION}

Hypertension is defined as elevated blood pressure and its prevalence is reported to be higher in urban than rural dwellers in sub-Saharan African countries, including Nigeria (Bunker et al., 1995; Rahman et al., 2006; Addo et al., 2007). The major risk factors to this health condition include cigarette smoking, age, plasma triglyceride, plasma low density lipoprotein cholesterol, plasma high density lipoprotein cholesterol, plasma urea nitrogen, urine protein, urine amino acid and fractional excretion of phosphorus, hypertensive heredity, diabetes and obesity amongst others (Nomiyama et al.,
2002). Exposure to heavy metals such as copper $(\mathrm{Cu})$, zinc $(\mathrm{Zn})$, lead $(\mathrm{Pb})$ and cadmium $(\mathrm{Cd})$ is also considered a contributing factor. All clinical symptoms emanating from metal toxicity are principally manifested in the blood; hence blood- $\mathrm{Pb}$ concentrations are usually representative of dose/exposure (Akanle, 1999; Staessen et al, 1991; Rahman et al., 2006).

There is increasing awareness of the role of trace metals in public health. Some of them such as $\mathrm{Cu}$ and $\mathrm{Zn}$ are essential to the fundamental biochemical and physiological functions of the cells and others such as $\mathrm{Pb}$ and $\mathrm{Cd}$ have no known beneficial use in the 
biological system, but all trace metals above the regulated concentrations, exhibit significant toxicity and increasing threat to environmental safety (WHO, 1995). Lead, found naturally in the environment, is known to be very toxic to living things and is present in the air, water, dust, soil, food and tissues of living organisms including humans (Ferguson, 1986; Nriagu et al., 1996; Sridhar, 2000).

Lead is a metal that has many important industrial uses and its relationship with blood pressure has received a great deal of attention due to the resulting mortality from cardiovascular and cerebrovascular diseases (Fenga et al., 2006; Rahman et al., 2006). Some studies have been carried out in Nigeria on the relationship between occupational exposure to $\mathrm{Pb}$, blood pressure and anthropometric parameters (Kadiri et al., 1999; Ademuyiwa et al., 2005; Dosunmu et al., 2005) but much less in relation to nonoccupational exposure. Several reports are documented that exposure to $\mathrm{Pb}$ is not exclusive to the occupationally exposed population but also to the non-occupationally exposed (Thomas et al., 1999; Rahman et al., 2006).

In this study, the relationships between blood lead level, total serum cholesterol, hematocrit (packed cell volume), age, body weight, body mass index, systolic blood pressure and diastolic blood pressure of 528 non-occupationally exposed male population (50\% cigarette smokers and 50\% nonsmokers) resident in Abeokuta, Nigeria were investigated. The effect of cigarette smoking on blood $\mathrm{Pb}$ level was also evaluated.

\section{MATERIALS AND METHODS Ethical consideration}

The research protocol was submitted to the committee for research on human subjects of the Federal Medical Centre (FMC), Abeokuta, Ogun State, Nigeria. Ethical clearance was obtained before the commencement of study and informed consent to participate was obtained from the respondents. Structured questionnaire was used to elicit relevant information. The exclusion criteria were all those who by their occupational inclination were directly exposed to $\mathrm{Pb}$, all those who had not been resident in Abeokuta for up to one year, all those who smoked less than five sticks of cigarettes per day, all those who stopped smoking less than one year from the day of this study, all those with drug/substance abuse or any form of mental disorder and all women.

\section{Study subject}

The target group consisted of 264 male smokers and 264 male non-smokers (control group), who were non-occupationally exposed to $\mathrm{Pb}$ and fall in the age range of 15 to 80 years, residing in Abeokuta metropolis, Nigeria.

\section{Sample collection and preservation}

Blood samples $(4 \mathrm{ml})$ collected by venipuncture from the smoking and nonsmoking subjects between 8.00 am and 12.00 noon on each sampling day in 2004 were stored in plastic tubes containing lithium heparinate as an anticoagulant. Before sampling, the venipuncture site was made lead free by rubbing with a solution of citric acid in alcohol (20 g/l, 70\% alcohol), followed by a $70 \%$ alcohol wash.

\section{Blood lead determination}

Prior to blood sample collection, blank tests for $\mathrm{Pb}$ were conducted on collection tubes, needles and syringes (from Norm-Ject Tuttligen, Germany) used for study to ensure that they were lead free. Consequently, each material was rinsed with $5 \mathrm{ml}$ of distilled water, saturated methyl isobutylketone (MIBK), allowed to stand for $4 \mathrm{hrs,} \mathrm{after}$ which $\mathrm{Pb}$ level in wash solution was measured using atomic absorption spectrophotometer (Perkin Elmer, Model 703; Illinois,USA).

Analytical procedure for the determination of lead in blood and urine using atomic absorption spectrometry described by Clinical and Laboratory Standards Institute, formerly NCCLS (2001) was utilized. The preserved blood samples were thawed and exactly $1 \mathrm{ml}$ of $0.1 \% \mathrm{HNO}_{3}$ (v/v) was added to a $50 \mu$ blood sample which was digested using the microwave digestion bomb (Parr Instrument Company, Moline, IL 61265) with a Teflon liner. After digestion, $0.1 \% \mathrm{HNO}_{3}$ $(\mathrm{v} / \mathrm{v})$ was added to the cooled digest at ratio 1:2 and ammonium hydrogen phosphate was added to the sample matrix to minimize interferents. The concentration of $\mathrm{Pb}$ in the digest was measured using the same atomic absorption spectrophotometer, which has 
basic operating characteristics as follows: wavelength of $283.9 \mathrm{~nm}$, slit width of $0.7 \mathrm{~nm}$ and gas mixture of air-acetylene.

\section{Hematocrit, cholesterol, blood pressure and body mass index determinations}

Packed cell volume or haematocrit was measured using micro-scale capillary tubes. Blood sample was taken up the capillary tube of dimension $75 \mathrm{~mm}$ (length), 1.1 to $1.2 \mathrm{~mm}$ (diameter) and $0.2 \mathrm{~mm}$ (thickness). The tube was transferred to a haematocrit centrifuge at $12,000 \mathrm{~g}$ for 5 minutes and the $\%$ hematocrit was recorded from the haematocrit reader.

The method of Roeschlau et al. (1974) was employed for serum cholesterol determination and ready to use reagent blank and standard in a kit made by Randox Laboratories Ltd, United Kingdom were used. Hence, $10 \mu \mathrm{l}$ each of blood sample, distilled water and standard were added to three different test-tubes. This was followed by the addition of $1000 \mu \mathrm{l}$ of the ready to use working reagent to each tube. The mixtures were incubated for 3 minutes at $37{ }^{\circ} \mathrm{C}$ and absorbance values read using a colorimeter fitted with a $500 \mathrm{~nm}$ filter, manufactured by Randox Laboratories Ltd, United Kingdom and results were expressed in $\mathrm{mg} / \mathrm{dl}$. The blood pressure level (systolic and diastolic) in $\mathrm{mmHg}$ were measured at 3 replicates for each subject using a sphygmanometer according to Famodu et al. (1998) and the body mass index was obtained by dividing the weight of subject by the square of the subject's height, expressed in $\mathrm{kg} / \mathrm{m}^{2}$.

\section{Statistical analysis}

Data were analysed using SPSS 10.0 statistical software for window. Descriptive statistics, t-test, One-way analysis of variance (ANOVA), and Pearson correlations were carried out to establish significant variations and relationships.

\section{RESULTS}

Tables 1 and 2 show the descriptive of biochemical variables for the general population of 528 subjects (test and control groups pooled together) and corresponding Pearson correlation coefficients ( $r$ ) for useful associations respectively with significant $\mathrm{r}$ values in the range of +0.626 to +0.887 ; $\mathrm{p} \leq 0.10$. Table 3 presents descriptive statistics of the variables for the respondents segregated in relation to cigarette smoking inclinations, regardless of age groups.

The mean blood $\mathrm{Pb}$ for smokers $(42 \pm$ $12 \mu \mathrm{g} / \mathrm{dl})$ was significantly higher than the value recorded for non-smokers $(34 \pm 11$ $\mu \mathrm{g} / \mathrm{dl})$ at $\mathrm{p}<0.001$. The hematocrit level or packed cell volume $(41 \pm 6 \%)$, serum cholesterol level $(151.4 \pm 4.48 \mathrm{mg} / \mathrm{dl})$ for smokers were also significantly different from the values $(39 \pm 6 \%$ and $132 \pm 43 \mathrm{mg} / \mathrm{dl}$ respectively) obtained for the non-smoking population. Some useful associations were also obtained between the blood biochemical variables for smokers and non-smokers (Table 4). Blood $\mathrm{Pb}$ related strongly and positively to systolic blood pressure of non-smokers $(\mathrm{r}=+$ $0.138 ; \mathrm{p}<0.05)$ and diastolic blood pressure

Table 1: Summary of variables in the general population.

\begin{tabular}{lccc}
\hline Variable & $\begin{array}{c}\text { Mean } \pm \text { SD } \\
(\mathbf{n}=\mathbf{5 2 8})\end{array}$ & Minimum & Maximum \\
\hline $\begin{array}{l}\text { Blood lead } \\
(\mu \mathrm{g} / \mathrm{dl})\end{array}$ & $37.9 \pm 4.5$ & 10 & 79 \\
\hline $\begin{array}{l}\text { Systolic blood pressure } \\
(\mathrm{mm} \text { Hg) }\end{array}$ & $119.5 \pm 6.0$ & 90 & 210 \\
\hline $\begin{array}{l}\text { Diastolic Blood } \\
\text { pressure }(\mathrm{mmHg})\end{array}$ & $78.7 \pm 3.0$ & 50 & 130 \\
\hline Hematocrit $(\%)$ & $39.8 \pm 1.3$ & 20 & 40 \\
\hline $\begin{array}{l}\text { Body mass index } \\
\left(\mathrm{kg} / \mathrm{m}^{2}\right)\end{array}$ & $22 \pm 0.95$ & 13 & 43 \\
\hline Body weight $(\mathrm{kg})$ & $62.9 \pm 10.2$ & 32 & 106 \\
\hline $\begin{array}{l}\text { Serum cholesterol } \\
(\mathrm{mg} / \mathrm{dl})\end{array}$ & $141.4 \pm 12.3$ & 45 & 293 \\
\hline Age $(\mathrm{yr})$ & $48 \pm 19$ & 15 & 80 \\
\hline
\end{tabular}


Table 2: Inter -variable bivariate Pearson correlations for the general study population regardless of smoking inclination.

\begin{tabular}{|c|c|c|c|c|c|c|}
\hline & $\begin{array}{c}\text { Systolic } \\
\text { blood } \\
\text { pressure }\end{array}$ & $\begin{array}{l}\text { Diastolic } \\
\text { blood } \\
\text { pressure }\end{array}$ & $\begin{array}{c}\text { Body mass } \\
\text { index }\end{array}$ & $\begin{array}{c}\text { Blood } \\
\text { Pb level }\end{array}$ & $\begin{array}{c}\text { Serum } \\
\text { cholesterol }\end{array}$ & Hematocrit \\
\hline $\begin{array}{l}\text { Systolic blood } \\
\text { pressure }\end{array}$ & +1.000 & $+0.717 * *$ & $+0.794 * *$ & +0.290 & +0.332 & -0.120 \\
\hline $\begin{array}{l}\text { Diastolic blood } \\
\text { pressure }\end{array}$ & & +1.000 & $+0.626^{*}$ & -0.101 & -0.031 & -0.369 \\
\hline Body mass index & & & +1.000 & +0.279 & +0.178 & -0.156 \\
\hline Blood $\mathrm{Pb}$ level & & & & +1.000 & $+0.887 * *$ & $+0.752 * *$ \\
\hline $\begin{array}{l}\text { Serum } \\
\text { cholesterol }\end{array}$ & & & & & +1.000 & $+0.831 * *$ \\
\hline Hematocrit & & & & & & +1.000 \\
\hline
\end{tabular}

Table 3: Descriptive statistics for variables of study population in relation to smoking inclination.

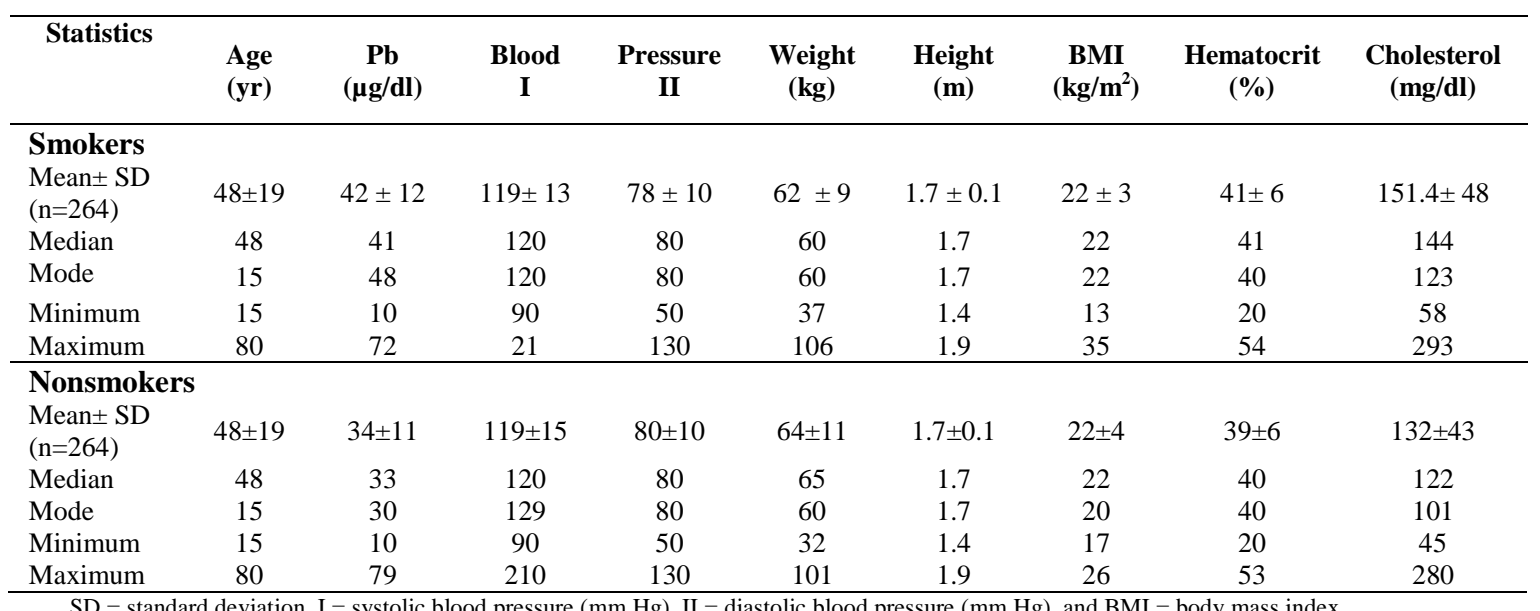

$\mathrm{SD}=$ standard deviation, $\mathrm{I}=$ systolic blood pressure $(\mathrm{mm} \mathrm{Hg}), \mathrm{II}=$ diastolic blood pressure $(\mathrm{mm} \mathrm{Hg})$, and $\mathrm{BMI}=$ body mass index.

for smokers $(\mathrm{r}=+0.129 ; \mathrm{p}<0.05)$. It also associated significantly with serum cholesterol $(\mathrm{r}=+0.114 ; \mathrm{p}<0.10)$ and body mass index for non - smokers $(r=+0.110$; $\mathrm{p} \leq 0.10$ ).

Systolic blood pressure related with age for both smokers $(\mathrm{r}=+0.272 ; \mathrm{p} \leq 0.001)$ and non-smokers $(\mathrm{r}=+0.388 ; \mathrm{p} \leq 0.001)$, body mass index for smokers $(\mathrm{r}=+0.224 ; \mathrm{p} \leq 0.001)$ and non-smokers $(\mathrm{r}=+0.182 ; \mathrm{p} \leq 0.10)$. Lastly, it gave significant correlation with serum cholesterol for non-smokers $(\mathrm{r}=$ $+0.151 ; \mathrm{p} \leq 0.05$ ) but a weak relationship with the values obtained for smokers $(r=+0.030$; $\mathrm{p}>0.10)$. Diastolic blood pressure levels significantly related to body mass index for both non - smokers $(\mathrm{r}=+0.105 ; \mathrm{p}<0.10)$ and smokers $(\mathrm{r}=+0.177 ; \mathrm{p} \leq 0.001)$ but a weak association with serum cholesterol levels for either smokers $(r=+0.027 ; p>0.10)$ or nonsmokers $(\mathrm{r}=+0.051 ; \mathrm{p}>0.10)$. It related significantly to the age of non - smokers $(\mathrm{r}=+$ $0.281 ; \mathrm{p}<0.001)$.

Hematocrit related significantly to total blood cholesterol level of smokers ( $\mathrm{r}=+$ $0.230 ; \mathrm{p}<0.001)$ and non-smokers $(\mathrm{r}=+$ 0.172; $\mathrm{p}=0.005$ ) but gave an indirect relationship with blood $\mathrm{Pb}$ level of smokers ( $\mathrm{r}$ $=-0.172 ; p=0.005)$. Analysis of variance gave significant variations $(\mathrm{p} \leq 0.05)$ for systolic blood pressure, diastolic blood pressure and blood lead levels for smokers but only diastolic blood pressure and body mass index differed significantly for non-smokers (Table 5). Significant and positive correlations (Table 6) were found between body weight and body mass index $(\mathrm{p} \leq 0.01)$, except for 
Table 4: Inter-variable bivariate Pearson correlations for study subjects in relation to their smoking inclination.

\begin{tabular}{|c|c|c|c|c|}
\hline \multirow{3}{*}{ Investigated variables } & \multicolumn{4}{|c|}{ Correlation coefficients (r) and level of significance (p) } \\
\hline & \multicolumn{2}{|c|}{ Smokers } & \multicolumn{2}{|c|}{ Non-smokers } \\
\hline & $\mathbf{r}$ & $\mathbf{P}$ & $\mathbf{r}$ & $\mathbf{P}$ \\
\hline Age versus systolic blood pressure & $0.272 * * *$ & 0.000 & $0.388 * * *$ & 0.000 \\
\hline $\begin{array}{l}\text { Age versus diastolic blood } \\
\text { pressure }\end{array}$ & 0.045 & 0.470 & $0.281 * * *$ & 0.000 \\
\hline $\begin{array}{l}\text { Age versus body mass index } \\
\text { (BMI) }\end{array}$ & 0.090 & 0.145 & $0.208 * * *$ & 0.001 \\
\hline Age versus cholesterol & 0.006 & 0.925 & 0.069 & 0.267 \\
\hline Age versus blood $\mathrm{Pb}$ & -0.053 & 0.389 & -0.075 & 0.224 \\
\hline Age versus hematocrit & 0.068 & 0.261 & 0.005 & 0.0938 \\
\hline BMI versus systolic blood pressure & $0.224 * * *$ & 0.000 & $0.182 * * *$ & 0.003 \\
\hline $\begin{array}{l}\text { BMI versus diastolic blood } \\
\text { pressure }\end{array}$ & $0.177 * * *$ & 0.001 & $0.105^{*}$ & 0.087 \\
\hline BMI versus cholesterol & $0.112 *$ & 0.069 & $0.141 * *$ & 0.022 \\
\hline BMI versus blood $\mathrm{Pb}$ & -0.033 & 0.596 & $0.110 *$ & 0.075 \\
\hline BMI versus hematocrit & $0.223 * * *$ & 0.000 & $0.106 *$ & 0.087 \\
\hline $\begin{array}{l}\text { Hematocrit versus systolic blood } \\
\text { pressure }\end{array}$ & -0.079 & 0.202 & 0.014 & 0.823 \\
\hline $\begin{array}{l}\text { Hematocrit versus diastolic blood } \\
\text { pressure }\end{array}$ & -0.040 & 0.522 & 0.007 & 0.914 \\
\hline Hematocrit versus cholesterol & $0.230 * * *$ & 0.000 & $0.172 * * *$ & 0.005 \\
\hline Hematocrit versus blood $\mathrm{Pb}$ & $-0.172 * * *$ & 0.005 & 0.039 & 0.526 \\
\hline $\begin{array}{l}\text { Cholesterol versus systolic blood } \\
\text { pressure }\end{array}$ & 0.030 & 0.623 & $0.151 * *$ & 0.014 \\
\hline $\begin{array}{l}\text { Cholesterol versus diastolic blood } \\
\text { pressure }\end{array}$ & 0.027 & 0.658 & 0.051 & 0.408 \\
\hline Cholesterol versus blood $\mathrm{Pb}$ & 0.041 & 0.507 & $0.114^{*}$ & 0.065 \\
\hline $\begin{array}{l}\text { Blood } \mathrm{Pb} \text { versus Systolic blood } \\
\text { pressure }\end{array}$ & 0.101 & 0.103 & $0.138 * *$ & 0.025 \\
\hline $\begin{array}{l}\text { Blood } \mathrm{Pb} \text { versus diastolic blood } \\
\text { pressure }\end{array}$ & $0.129 * *$ & 0.036 & 0.033 & 0.590 \\
\hline
\end{tabular}

age group 25 to 34 years, with the coefficient (r) ranging from +0.683 to +0.885 . Body mass index associated positively with total blood cholesterol for age groups 25 to 34 and 45 to 54 years $(\mathrm{r}=+0.267$ to 0.345$)$.

Blood cholesterol related to body weight for non-smokers within 65 to 74 years old with $\mathrm{r}=+0.472$ at $\mathrm{p}=0.01$. Blood $\mathrm{Pb}$ related with systolic blood pressure $(\mathrm{r}=+$ 0.293 to +0.57 ) except in age group 15 to 24 years. The level of significance was highest for respondents in ages 45 to 64 and 75 to 80 years $(p \leq 0.05)$. Age gave significant relationship with systolic blood pressure and blood $\mathrm{Pb}$ level for respondents between 15 to 24 years and 45 to 54 years with the coefficient in the rage of +0.321 to +0.434 .

\section{DISCUSSION}

Results from this study are consistent with previous works which revealed that $\mathrm{Pb}$ in the blood of most Nigerian respondents exceeded $10 \mu \mathrm{g} / \mathrm{dl}$. In their isolated studies with study populations in the range of 40 to 880, Olubajo et al. (1992) reported $25.6 \mu \mathrm{g} / \mathrm{dl}$ in selected university male undergraduates of Lagos and 12 to $13 \mu \mathrm{g} / \mathrm{dl}$ were recorded in some adult populations resident in Lagos, 
Table 5: Comparative evaluation of the variables in smokers and non-smokers in relation to age.

\begin{tabular}{|c|c|c|c|c|c|c|}
\hline $\begin{array}{l}\text { Age range } \\
\text { (Year) }\end{array}$ & $\begin{array}{l}\text { Systolic blood } \\
\text { pressure } \\
(\mathrm{mmHg})\end{array}$ & $\begin{array}{l}\text { Diastolic blood } \\
\text { pressure } \\
(\mathrm{mmHg})\end{array}$ & $\begin{array}{l}\text { BMI } \\
\left(\mathrm{kg} / \mathrm{m}^{2}\right)\end{array}$ & $\begin{array}{l}\text { Hematocrit } \\
(\%)\end{array}$ & $\begin{array}{l}\text { Cholesterol } \\
(\mu \mathrm{g} / \mathrm{dl})\end{array}$ & $\begin{array}{l}\text { Pb level } \\
(\mu \mathrm{g} / \mathrm{dl})\end{array}$ \\
\hline \multicolumn{7}{|l|}{ Smokers } \\
\hline $15-24$ & $108.8 \pm 10.7^{\mathrm{a}}$ & $75.3 \pm 8.2^{\mathrm{a}}$ & $21.1 \pm 2.3^{\mathrm{a}}$ & $40.1 \pm 5.0^{\mathrm{a}}$ & $150.9 \pm 49.4^{\mathrm{a}}$ & $42.8 \pm 11.7^{\mathrm{a}}$ \\
\hline $25-34$ & $117.0 \pm 11.6^{b}$ & $77.3 \pm 9.6^{\mathrm{ab}}$ & $21.5 \pm 2.6^{\mathrm{a}}$ & $39.8 \pm 5.6^{\mathrm{a}}$ & $144.8 \pm 61.5^{\mathrm{a}}$ & $42.6 \pm 11.6^{\mathrm{a}}$ \\
\hline $35-44$ & $123.8 \pm 14.4^{b}$ & $81.0 \pm 10.6^{\mathrm{b}}$ & $23.5 \pm 4.0^{\mathrm{b}}$ & $42.2 \pm 4.9^{a}$ & $161.8 \pm 45.6^{\mathrm{a}}$ & $44.0 \pm 13.6^{\mathrm{a}}$ \\
\hline $45-54$ & $121.5 \pm 11.0^{b}$ & $77.1 \pm 10.2^{\mathrm{ab}}$ & $22.0 \pm 2.9^{\mathrm{a}}$ & $39.8 \pm 7.1^{\mathrm{a}}$ & $144.7 \pm 40.3^{\mathrm{a}}$ & $38.52 \pm 11.5^{\mathrm{a}}$ \\
\hline $55-64$ & $121.0 \pm 19.2^{b}$ & $78.0 \pm 13.0^{\mathrm{ab}}$ & $21.5 \pm 3.4^{\mathrm{a}}$ & $40.8 \pm 4.9^{\mathrm{a}}$ & $152.0 \pm 48.5^{\mathrm{a}}$ & $40.8 \pm 13.4^{\mathrm{a}}$ \\
\hline $65-74$ & $122.8 \pm 10.4^{b}$ & $79.8 \pm 9.5^{\mathrm{ab}}$ & $22.3 \pm 2.4^{\mathrm{ab}}$ & $41.3 \pm 5.4^{\mathrm{a}}$ & $155.4 \pm 43.5^{\mathrm{a}}$ & $42.1 \pm 9.2^{\mathrm{a}}$ \\
\hline $75-80$ & $120.8 \pm 10.6^{b}$ & $75.0 \pm 9.3^{\mathrm{a}}$ & $22.4 \pm 1.9^{\mathrm{ab}}$ & $41.1 \pm 5.1^{\mathrm{a}}$ & $149.3 \pm 36.9^{\mathrm{a}}$ & $41.4 \pm 13.5^{\mathrm{a}}$ \\
\hline \multicolumn{7}{|c|}{ Non-smokers } \\
\hline $15-24$ & $105.8 \pm 8.7^{\mathrm{a}}$ & $75.5 \pm 7.5^{\mathrm{a}}$ & $20.1 \pm 2.7^{\mathrm{a}}$ & $38.0 \pm 5.2^{\mathrm{a}}$ & $119.3 \pm 23.5^{\mathrm{a}}$ & $33.4 \pm 10.2^{\mathrm{ab}}$ \\
\hline $25-34$ & $116.8 \pm 9.7^{b}$ & $74.8 \pm 7.4^{\mathrm{a}}$ & $22.2 \pm 3.3^{b}$ & $39.9 \pm 5.9^{\mathrm{a}}$ & $137.3 \pm 37.8^{\mathrm{a}}$ & $36.4 \pm 12.5^{\mathrm{ab}}$ \\
\hline $35-44$ & $116.8 \pm 13.3^{b}$ & $78.8 \pm 9.7^{\mathrm{ab}}$ & $23.3 \pm 4.4^{\mathrm{b}}$ & $39.0 \pm 5.4^{\mathrm{a}}$ & $124.1 \pm 51.0^{\mathrm{a}}$ & $34.8 \pm 14.1^{\mathrm{ab}}$ \\
\hline $45-54$ & $123.0 \pm 21.7^{b c}$ & $83.3 \pm 13.3^{\mathrm{b}}$ & $22.6 \pm 3.1^{\mathrm{b}}$ & $39.4 \pm 6.1^{\mathrm{a}}$ & $140.0 \pm 43.1^{\mathrm{a}}$ & $36.8 \pm 11.4^{b}$ \\
\hline $55-64$ & $128.0 \pm 12.6^{\mathrm{c}}$ & $82.3 \pm 10.3^{\mathrm{b}}$ & $23.5 \pm 2.4^{\mathrm{b}}$ & $39.9 \pm 6.1^{\mathrm{a}}$ & $139.5 \pm 44.0^{\mathrm{a}}$ & $30.6 \pm 9.3^{\mathrm{a}}$ \\
\hline $65-74$ & $123.8 \pm 13.1^{\mathrm{c}}$ & $82.8 \pm 9.3^{\mathrm{b}}$ & $22.6 \pm 4.1^{b}$ & $39.2 \pm 5.8^{\mathrm{a}}$ & $132.3 \pm 50.6^{\mathrm{a}}$ & $33.3 \pm 11.4^{\mathrm{ab}}$ \\
\hline $75-80$ & $122.5 \pm 10.3^{b c}$ & $81.3 \pm 10.3^{\mathrm{b}}$ & $22.4 \pm 2.6^{\mathrm{b}}$ & $37.0 \pm 6.2^{\mathrm{a}}$ & $128.8 \pm 40.9^{\mathrm{a}}$ & $32.4 \pm 11.8^{\mathrm{ab}}$ \\
\hline
\end{tabular}

Table 6: Useful correlations within age groups, segregated in relation to smoking inclination.

\begin{tabular}{|c|c|c|c|c|c|}
\hline \multirow{2}{*}{$\begin{array}{c}\text { Age group } \\
\text { (Years) }\end{array}$} & \multirow{2}{*}{ Paired variable } & \multicolumn{2}{|c|}{ Smoker } & \multicolumn{2}{|c|}{ Non-smoker } \\
\hline & & $\mathbf{r}$ & p - level & $\mathbf{r}$ & p-level \\
\hline \multirow{2}{*}{$15-24$} & Age versus Systolic pressure & 0.434 & 0.01 & 0.439 & 0.01 \\
\hline & BMI versus body weight & 0.841 & 0.01 & 0.753 & 0.01 \\
\hline \multirow{3}{*}{$25-34$} & Age versus body weight & 0.335 & 0.05 & 0.432 & 0.01 \\
\hline & Body mass index versus cholesterol & 0.366 & 0.05 & 0.267 & 0.10 \\
\hline & $\begin{array}{l}\text { Body mass index versus systolic } \\
\text { pressure }\end{array}$ & NS & NS & 0.293 & 0.10 \\
\hline \multirow{6}{*}{$35-44$} & BMI versus systolic pressure & 0.405 & 0.01 & 0.413 & 0.01 \\
\hline & BMI versus diastolic pressure & 0.525 & 0.01 & 0.379 & 0.05 \\
\hline & BMI versus hematocrit & 0.310 & 0.10 & 0.310 & 0.10 \\
\hline & BMI versus body weight & 0.885 & 0.01 & 0.830 & 0.01 \\
\hline & Cholesterol versus blood $\mathrm{Pb}$ & 0.294 & 0.001 & 0.001 & NS \\
\hline & Blood $\mathrm{Pb}$ versus systolic pressure & 0.106 & NS & 0.293 & 0.10 \\
\hline \multirow{5}{*}{$45-54$} & Age versus systolic pressure & 0.321 & 0.05 & NS & NS \\
\hline & BMI versus cholesterol & 0.03 & NS & 0.341 & 0.05 \\
\hline & BMI versus body weight & 0.794 & 0.01 & 0.788 & 0.01 \\
\hline & Blood $\mathrm{Pb}$ versus systolic pressure & NS & NS & 0.530 & 0.01 \\
\hline & Blood $\mathrm{Pb}$ versus diastolic pressure & NS & NS & 0.389 & 0.05 \\
\hline \multirow{4}{*}{$55-64$} & Age versus blood $\mathrm{Pb}$ & NS & NS & 0.270 & NS \\
\hline & BMI versus body weight & 0.825 & 0.01 & 0.689 & 0.01 \\
\hline & Blood $\mathrm{Pb}$ versus systolic pressure & 0.418 & 0.05 & NS & NS \\
\hline & Blood $\mathrm{Pb}$ versus diastolic pressure & 0.397 & 0.05 & NS & NS \\
\hline \multirow{3}{*}{$65-74$} & BMI versus body weight & 0.684 & 0.01 & NS & NS \\
\hline & Hematocrit versus cholesterol & 0.491 & 0.01 & 0.493 & 0.01 \\
\hline & Cholesterol versus body weight & NS & NS & 0.472 & 0.01 \\
\hline \multirow[b]{2}{*}{$75-80$} & $\begin{array}{l}\text { Body mass index versus body } \\
\text { weight }\end{array}$ & 0.711 & 0.01 & 0.638 & 0.01 \\
\hline & $\begin{array}{l}\text { Blood-Pb versus systolic blood } \\
\text { pressure }\end{array}$ & NS & NS & 0.572 & 0.01 \\
\hline
\end{tabular}


Ibadan and Ife (Omokhodion, 1994), while $27.7 \pm 6.6$ to $30.1 \pm 1.47 \mu \mathrm{g} / \mathrm{dl}$ were recorded for subjects from some cities in southwest Nigeria (Adeniyi and Anetor, 1999). The works of Ademuyiwa et al. (2002) gave $16.27 \pm 2.65 \mu \mathrm{g} / \mathrm{dl}$ for some university undergraduates in Abeokuta and 43.26 \pm 4.28 ; $32.44 \pm 3.02 \mu \mathrm{g} / \mathrm{dl}$ were recorded by Babalola et al. (2007) for some male cigarette smokers and non-smokers respectively. Top on the list of causative factors to elevated blood $\mathrm{Pb}$ level in Nigeria is the use of leaded-gasoline (Nriagu et al., 1996; Wright et al., 2005).

Blood $\mathrm{Pb}$ concentrations found in this study were higher than the $13.9 \mu \mathrm{g} / \mathrm{dl}$ recorded by Rahman et al. (2006) for the nonoccupationally exposed in Pakistani adults but compared with the mean value of $42.33 \pm$ $15.16 \mu \mathrm{g} / \mathrm{dl}$ recorded by Fenga et al. (2006) for the occupationally exposed (exhaust battery storage workers) in Italy. This indicates increased $\mathrm{Pb}$ concentration in the Nigerian environment.

The useful relationships obtained in this study for blood $\mathrm{Pb}$ level, systolic blood pressure, diastolic blood pressure, serum cholesterol and body mass index are supported by literature reports. Bunker et al. (1995) in their study on some Nigerian population, consisting of 500 males and 299 females civil servants, reported a relationship between body mass index and blood pressure at a BMI threshold of $21.5 \mathrm{~kg} / \mathrm{m}^{2}$. However, Kaufman et al. (1997) reported that above this threshold, there was positive and significant relationship between body mass index and systolic blood pressure for females only.

Anderson et al. (1994) stated that weight reduction leads to reduced cardiovascular risk factors such as serum cholesterol, low density lipoprotein cholesterol, triglycerides, systolic blood pressure and diastolic blood pressure. Telisman et al. (2004) corroborated this by reporting that an increase in systolic blood pressure or diastolic blood pressure was associated with increasing erythrocyte protoporphyrin, body mass index and blood $\mathrm{Pb}$, recording an increase of $17 \mathrm{mmHg}$ in systolic blood pressure and $6 \mathrm{mmHg}$ in diastolic blood pressure in moderately leadexposed workers.

A strong and positive association between blood $\mathrm{Pb}$ and cholesterol was also reported by Ademuyiwa et al. (2005), who opined that exposure to $\mathrm{Pb}$ increases cholesterol synthesis and transport to peripheral tissues. It might also not be unassociated with cholesterol's chemical nature, which is a fatlike steroid alcohol. In assessing the combined influence of blood pressure, serum cholesterol level and cigarette smoking on death from coronary heart disease, strong graded relationships between serum cholesterol levels above $180 \mathrm{mg} / \mathrm{dl}$, systolic blood pressure above $110 \mathrm{mmHg}$ and diastolic blood pressure above $70 \mathrm{mmHg}$ were evident for 316, 099 men (Neaton and Wentworth, 1992). Along with high blood pressure and cigarette smoking, cholesterol is one of the three major modifiable risk factors of coronary heart disease (Neaton and Wentworth, 1992; D’Agostino et al., 1995; Nomiyama et al., 2002).

Rahman et al. (2006) stated that increasing systolic blood pressure was significantly predictive of increasing blood $\mathrm{Pb}$ level and that body mass index, lipid profiles including total cholesterol, low density lipoprotein cholesterol, high density lipoprotein cholesterol and triglyceride correlated with blood pressure. Nomiyama et al. (2002) reported that blood $\mathrm{Pb}$ above 40 $\mu \mathrm{g} / \mathrm{dl}$ was found to be the most potent factor for elevated systolic and diastolic blood pressure levels, insinuating that $\mathrm{Pb}$ induced changes in lipoprotein metabolism may play an important role in the $\mathrm{Pb}$ induced blood pressure increase.

Fenga et al. (2006) discovered that long term exposure to $\mathrm{Pb}$ was related to a slight increase in both systolic and diastolic pressure among workers and Nash et al. (2003) related blood $\mathrm{Pb}$ to blood pressure and hypertension in premenopausal women. Menditto et al. (1994) showed that median blood $\mathrm{Pb}$ values increased significantly by $2.3 \%$ from 11.10 to $11.35 \mu \mathrm{g} / \mathrm{dl}$ in subjects with borderline blood pressure. They also reported significant linear correlation coefficient $(\mathrm{r})$ between blood $\mathrm{Pb}$ and both systolic blood pressure and diastolic blood pressure with $r=0.1332$ and 0.0732 at $\mathrm{p}<0.001$. Their multiple regression analyses revealed that body mass index, age, heart rate, skinfold thickness, serum lipids, glucose levels and blood $\mathrm{Pb}$ level were still significant predictors of increased systolic blood pressure and diastolic blood pressure. 
Results from this study showed that cigarette smoking was a factor to increased blood $\mathrm{Pb}$, increasing it by approximately $24 \%$ which is in agreement with the results of Babalola et al. (2007) that reported an increment of $33 \%$. It is reported that a typical cigarette contains $\mathrm{Pb}$ in the range of 0.2 to 12 $\mu \mathrm{g}$ and helps to build up $\mathrm{Pb}$ levels in smokers by more than $10 \%$ (Kumar et al., 1993; WHO, 1995). Increased blood lead concentration for smokers was also attributed to augmented alcohol intake, corroborated by the works of Grandjean et al. (1981), Schumacher et al. (1993) and Ugoala (1999) that showed correlations between alcohol consumption and lead levels in smokers.

In the context of clinical guideline for blood cholesterol levels $(<200 \mathrm{mg} / \mathrm{dl}$ for normal, 200 to $239 \mathrm{mg} / \mathrm{dl}$ for borderline and $>240 \mathrm{mg} / \mathrm{dl}$ for elevated blood cholesterol) reported by Freedman et al. (1995), the mean cholesterol levels for both smokers and nonsmokers obtained in this study (141.4 \pm 12.3 $\mathrm{mg} / \mathrm{dl})$ fell within the acceptable limit. However, the range (45 to $293 \mathrm{mg} / \mathrm{dl}$ ) implied that some subjects were obviously characterized by high cholesterol level. Hypercholesterolemia (high blood cholesterol) is not a disease but a metabolic situation that can be secondary to other diseases notably cardiovascular disease, which is associated with coronary disease, circulatory problems and hypertension (Freedman et al., 1995).

\section{Conclusion}

This study revealed that cigarette smoking increased blood $\mathrm{Pb}$ and interwoven relationships between blood lead, blood pressure (systolic and diastolic), serum cholesterol, age and body mass index of nonoccupationally exposed males, resident in Abeokuta, Nigeria were established.

\section{ACKNOWLEDGEMENTS}

The Management and Staff of Federal Medical Centre, Abeokuta, Sacred Heart Hospital Abeokuta and the Commandant 321 Artillery Regiment Abeokuta are acknowledged for permitting their patients and staff to participate in this study.

\section{REFERENCES}

Ademuyiwa O, Ugboaja RN, Idumebor F, Adebawo O. 2005. Plasma lipid profiles and risk of cardiovascular disease in occupational lead exposure in Abeokuta, Nigeria. Lipid in Health and Diseases, 4: 19 doi: 10.1186/1476-511x-4-19. Available on line at htt://www.lipidworld. com/content/4/1/19.

Ademuyiwa O, Arowolo TA, Ojo DA, Odukoya OO, Yusuf AA, Akinhanmi TF. 2002. Lead levels in blood and urine of some residents of Abeokuta, Nigeria. Trace Elements and Electrolytes, 192: 6369.

Adeniyi FAA, Anetor JF. 1999. Leadpoisoning in two distant states of Nigeria: an indication of the real size of the problem. Afr. J. Med. Sci., 28: 107-112.

Addo J, Smith L, Leon DA. 2007. Hypertension in sub-saharan Africa: a systematic review. Hypertension, 50: 1012-1018.

Akanle OA, Akintanmide A, Durosinmi MA, Oluwole AF, Sprou NM. 1999. Elemental analysis of blood of Nigerian hypertensive subjects. Biological Trace Elements Research, 70/71: 611 -616.

Anderson JW, Brinkman-Kaplan VL, Lee H, Wood CL. 1994. Relationship of weight loss to cardiovascular risk factors in morbidly obese individuals. Journal of the American College of Nutrition, 13: $3252-3261$.

Babalola OO, Adekunle IM, Okonji RE, EjmEze E, Terebo O. 2007. Selected heavy metals in blood of male Nigerian smokers. Pakistan Journal of Biological Sciences, 10(20): 3730-3733.

Bunker CH, Ukoli FA, Mathews KA, Kriska AM, Huston SL, Kuller LH. 1995. Weight threshold and blood pressure in a lean black population. Hypertension, 26: 616-623.

Clinical and Laboratory Standards Institute. 2001. Analytical procedure for the determination of lead in blood and urine; Approved Guideline. Parson PT, Chisolm JJ, Trevor H, Griffin DR, Gunter EW, Salvin W, Stanton NV, Vocke R (ed). NCCLS document, C40-A, (ISBN 156238-437-6), USA, p.1-92.

D'Agostino RB, Belanger AJ, Kannel WB, Higgins M. 1995. Role of smoking in the U-shaped relation of cholesterol to mortality in men: the Framingham study. J. Epidemiol., 141(9): 822 -827. 
Dosumu O, Onunkwor B, Odukoya O, Arowolo T, Ademuyiwa O. 2005. Biomarkers of lead exposure in automechanics in Abeokuta, Nigeria. Trace Elements and Electrolytes, 22(3): 185191.

Famodu AA, Osilesi O, Makinde YO, Osonuga OA. 1998. Blood pressure and blood lipid levels among vegetarian, semi-vegeterian and non-vegetarian native. Afr. Clin. Biochem., 317: 545-549.

Fenga C, Cacciola A, Martino LB, Calderadro SR, Di Nola C, Verzera A, Trimarchi G, Gerano D. 2006. Relationship of blood lead levels to blood pressure in exhaust battery storage workers. Industrial Health, 44: 304- 309.

Ferguson JE. 1986. Petrol leads in environment and its contribution to human lead levels. Sci. Total Environ., 50:1-54.

Freedman DS, Byers T, Barrett DH, Estroup NE, Eaker E, Monroe-Blum H. 1995. Plasma lipid levels and psychologic characteristics in men. Am. J. Epidemiol., 141(6): 507-517.

Grandjean P, Olsen NB, Hollnagel H. 1981. Influence of smoking and alcohol consumption on blood lead levels. Int. Arch. Occup. Environ. Health, 48(4): 391-397.

Kadiri S, Walker O, Salako BL, Akinkugbe O. 1999. Blood pressure, hypertension and correlates in urbanized workers in Ibadan, Nigeria-a revisit. J. Hum. Hypertens., 13: 23-27.

Kaufman JS, Asuzu MC, Mufunda J, Forrester T, Wilks R, Luke A, Long AE, Cooper RS. 1997. Relationship between blood pressure and body mass index in lean populations. Hypertension, 30: 15111516.

Kumar S, Kaushik A, Kaushik CP. 1993. Blood lead levels among populations differently exposed to vehicular exhaust in Rohtak, India. Environmental Pollution, 80: 173 - 176.

Menditto A, Morisi G, Spagndo A, Menotti A. 1994. Association of blood $\mathrm{Pb}$ to blood pressure in men aged 55 to 75 years: effect of selected social and biochemical confounders. Environ Health Perspectives, 102(9): 107-111.
Nash D, Magder L, Lusberg M, Sherwin RW, Rubin RJ, Kaufman RB, Silbergeld, EK. 2003. Blood lead, blood pressure and hypertension in premenopausal women. $J$. Am. Med. Assoc., 289: 1523-1532.

Neaton, JD, Wentworth, D.1992. Serum cholesterol, blood pressure, cigarette smoking and death from coronary heart disease. Arch. Intern. Med., 152(1): 5664.

Nomiyama K, Nomiyama H, Liu S-J, Tao YX, Nomiyama T, Omae K. 2002. Lead induced increase of blood pressure in female lead workers. Occupational and Environmental Medicine, 59: 734-738.

Nriagu JO, Blackson Ocram K. 1996. Childhood lead poisoning in Africa: a growing public health problem. Sci. Tot Environ., 181(2): 93 -101.

Olubajo O, Egun GN, Owolajamoh AA, William OB, Moses A. 1992. Blood lead values in occupationally exposed workers in Lagos, Nigeria. Bio. Sci. Res. Commun., 41: 47 -52.

Omokhodion OF. 1994. Blood lead and tap water lead in Ibadan, Nigeria. Sci. Tot. Environ., 151:187-190.

Rahman S, Khalid N, Zaidi ZH, Ahmad S, Iqbal MZ. 2006. Non-occupational lead exposure and hypertension in Pakistani adults. J. Zhejiang Univ. Science B., 7(9): 732-737.

Roeschlau P, Bernt E, Gruber W. 1974. Enzymatic determination of total cholesterol in serum. J. Clin. Chem. Clin. Biochem., 12: 227.

Schumacher M, Domingo LL, Llober JM, Corbella J. 1993. Variability of blood lead level in an urban population in relation to drinking and smoking habits. Sci. Tot. Environ., 138: 23-29.

Sridhar MKC, Adogame L, Olawuyi J. 2000. Lead exposure in urban cities: a case study from Ibadan, Nigeria. Epidemiolog., 10(22): 227.

Staessen J, Amery A, Bernard A. 1991. Blood pressure, the prevalence of cardiovascular disease and exposure to cadmium: a population study. Am. J. Epidemiol., 134: 2576-267.

Telisman S, Pizent A, Jurasovic J, Cvitkovic P. 2004. Lead effect on blood pressure in moderately lead-exposed male workers. 
American Journal of Industrial Medicine, 45(5): 446-454.

Thomas VM, Socolow RH, Fanelli JJ, Spiro TG. 1999. Effects of reducing lead in gasoline: an analysis of the international experience. Environ Sci. Technol., 33: 3942-3948.

Ugoala VP. 1999. The black hypertension story: haemodynamics, genetic factors and therapeutic considerations. Dokita, 26:1:97-104.

WHO (World Health Organization). 1995. Environmental Health Criteria 3. Lead World Health Organization. Geneva.

Wright NJ, Thacher TD, Pfotzner MA, Fischer PR, Pettifor JM. 2005. Causes to lead toxicity in a Nigerian city. Archives of Diseases in Childhood, 90: 262-266. 